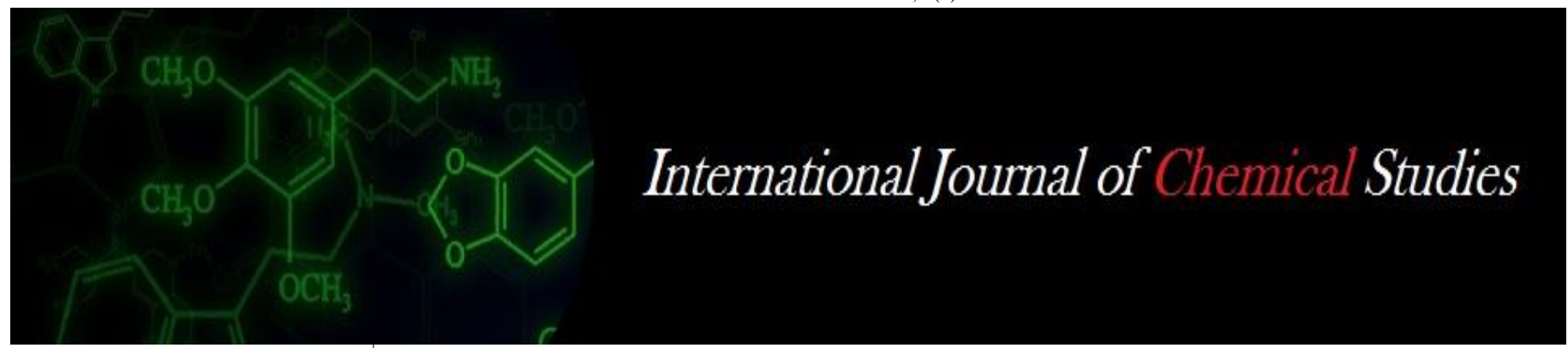

P-ISSN: 2349-8528

E-ISSN: 2321-4902

www.chemijournal.com

IJCS 2020; 8(6): 1170-1172

(C) 2020 IJCS

Received: 24-09-2020

Accepted: 26-10-2020

Vivek Kashyap

Department of Plant Pathology,

College of Agriculture,

RVSKVV, Gwalior, Madhya

Pradesh, India

Jagdish Kumar Patidar

Department of Plant Pathology,

College of Agriculture,

RVSKVV, Gwalior, Madhya

Pradesh, India

Reeti Singh

Department of Plant Pathology,

College of Agriculture,

RVSKVV, Gwalior, Madhya

Pradesh, India

\section{RK Pandya}

Department of Plant Pathology, College of Agriculture,

RVSKVV, Gwalior, Madhya

Pradesh, India
Corresponding Author:

Vivek Kashyap

Department of Plant Pathology,

College of Agriculture,

RVSKVV, Gwalior, Madhya

Pradesh, India

\section{Occurrence and distribution of chickpea wilt in central part of India}

\author{
Vivek Kashyap, Jagdish Kumar Patidar, Reeti Singh and RK Pandya
}

DOI: $\underline{\text { https://doi.org/10.22271/chemi.2020.v8.i6q.10920 }}$

\begin{abstract}
A survey was conducted in 2014-2015 Rabi season to obtain information on the distribution and incidence of chickpea wilt in respect of soil type and irrigation condition. Local cultivars predominant in most farmer's field. Wilt disease was found at all the sites and incidence ranged from 1.69 to $18.67 \%$ irrespective of cultivar type and locations. The result indicated that wilt is recently highly distributed in all visited chickpea growing areas of the central part of India. The wilt incidence was more in rainfed condition (11.37\%) as compared to irrigated condition $(7.56 \%)$. On the basis of the survey, deep black soil was found most suitable for wilt development,
\end{abstract}

Keywords: Survey, Chickpea wilt, disease incidence, soil type, irrigation condition

\section{Introduction}

Chickpea (Cicer arietinum L.) is an important pulse crop, which belongs to Leguminoceae family, ranking third after dry beans (Phaseolus vulgaris L.) and dry peas (Pisum sativum L.) The centre of origin of chickpea is in Eastern Mediterranean (Aykoid and Doughty, 1964). India is largest producer of chickpea in world sharing 66.78 per cent in area and 66.13 per cent in production (Anon. 2018a) ${ }^{[1]}$. In India, chickpea is grown on 10.56 million ha area with production 12.30 million tonnes and productivity $1063 \mathrm{~kg} / \mathrm{ha}$. The production of chickpea in Madhya Pradesh is 4.60 million tonnes with productivity $1280 \mathrm{~kg} / \mathrm{ha}$ which covered nearly 3.59 million ha of area. Madhya Pradesh contributes about 40.92 per cent share in total production of country (Anon., 2018b) ${ }^{[2]}$. It is the important grain legume grown for protein rich seeds for human consumption and to maintain the soil fertility by its nitrogen fixing capability. Chickpea seeds contain $20 \%$ protein, $64 \%$ carbohydrates, $47 \%$ starch, $5 \%$ fat, $6 \%$ crude fibre, $6 \%$ soluble sugar and $3 \%$ ash, minerals such as calcium (202 mg), phosphorus (312mg), iron $(10.2 \mathrm{mg})$, vitamin $\mathrm{C}(3.0 \mathrm{mg})$, calorific value $(360 \mathrm{cal})$, small amounts of B complex, fibre (3.9g) and moisture (9.8g) (Dhawan et al., 1991) ${ }^{[5]}$.

F. oxysporum Schlechtend. Fr. f. sp. ciceris (Padwick) Matuo and K. Sato causing Fusarium vascular wilt is the major limiting factor in chickpea production (Jalali and Chand, 1992; Haware, 1990 and Nene and Reddy, 1987) ${ }^{[9,8,14]}$. It was first reported in Indo-Pak subcontinent (Butler, 1918) ${ }^{[4]}$. In general, the disease causes substantial yield losses which may reach even 100 per cent under favourable weather conditions (Jalali and Chand, 1992) ${ }^{[9]}$. A comprehensive survey of chickpea diseases in central parts of India was conducted in 20142015. The objectives of the survey were: (1) to find out the occurrence and distribution of chickpea wilt; (2) to find out the incidence of the wilt; 3 ) to assess the effect of irrigation or rainfed condition on the development of the wilt.

\section{Methods}

The survey for the occurrence and severity of chickpea wilt was made during crop season 2014-15. Observation was recorded mostly from farmers field under natural conditions. Data were recorded at different places and dates. The five fields of each place were selected at random. Irrigation condition and soil type also recorded for each place. Five hundred plants were taken randomly from the field and the number of diseased and healthy plants were then sorted out. Disease incidence was calculated by using the formula given below and expressed in percentage. 
Wilt incidence $\%=\frac{\text { Diseased plants }}{\text { Total number of plants }} \times 100$

The percentage infection of each field in a place was used for calculating the place average. The sample was critically examined for the presence of causal organism.

\section{Result and discussion}

\section{1: Diseases and Regions}

During the investigation 40 places visited under 15 districts viz., Gwalior (2), Shivpuri (5), Guna (4) Rajgarh (2), Sajapur (2), Sehore (1), Dewas (1), Indore (1), Khargone (4), Khandwa (2) Burhanpur (2), Barwani (4), Alirajpur (2), Jhabua (2) and Dhar (6) and wilt incidence was recorded. Wilt was found at all the sites and the incidence ranged from 1.69 to $18.67 \%$. The mean maximum wilt incidence incidence was recorded in Jhabua (18.67\%) followed by Sardarpur (18.61\%), Bhurhanpur (18.28\%), Sendwa (17.69\%), Bhikangaon (17.68\%) and Bagh (17.35\%), while Mohana $(1.69 \%)$ followed by Guna (1.94\%), Ghatigaon (2.87\%), Binaganj (3.93\%), Lukwasa (4.53), Goda (5.29\%) and Kolarash (6.14\%). Ghosh et al. (2013) ${ }^{[7]}$ conducted the survey from central and southern parts of India and reported that the incidence of wilt and black root rot disease ranged from $9.7 \%-13.8 \%$ and $6.6 \%-7.4 \%$ respectively. Dubey et al. (2010) [6] surveyed different states of India, namely Punjab, Haryana, Delhi, Rajasthan and Jharkhand and reported that the incidence of wilt in the areas surveyed varied from 14.1 to $32.0 \%$ with the maximum in the Rajasthan state followed by Jharkhand and the minimum in the state of Punjab.

\section{2: Diseases and irrigation conditions}

During the investigation, 27 places found in rainfed condition, while 13 places were found in irrigated condition. Data presented in table-1 revealed that the wilt incidence found more severe from rainfed condition (11.37\%) compare to irrigated condition (7.65\%). Mina and Dubey (2010) reported that soil moisture was found negatively correlated with wilt incidence of chickpea. Abiotic factors, including soil moisture and temperature, can significantly influence the development of Fusarium wilt of chickpeas (Bhatti and Kraft, 1992; NavasCortés et al., 2000) ${ }^{[3,13]}$.

Table 1: Prevalence of chickpea diseases in Central Part of India during rabi (2014-15)

\begin{tabular}{|c|c|c|c|c|c|c|}
\hline \multirow{2}{*}{ S. No. } & \multirow{2}{*}{ Name of the village visited } & \multirow{2}{*}{ District } & \multirow{2}{*}{ Rainfed/irrigated } & \multirow{2}{*}{ Soil type } & \multicolumn{2}{|c|}{ Fusarium wilt } \\
\hline & & & & & Rang & Average \\
\hline 1 & Ghatigaon & Gwalior & Rainfed & Alluvial Soil & $1-5 \%$ & 2.87 \\
\hline 2 & Mohana & Gwalior & Rainfed & Alluvial Soil & $1-3 \%$ & 1.69 \\
\hline 3 & Lukwasa & Shivpuri & Rainfed & Alluvial Soil & $2-8 \%$ & 4.53 \\
\hline 4 & Goda & Shivpuri & Rainfed & Alluvial Soil & $3-7 \%$ & 5.27 \\
\hline 5 & Shivpuri & Shivpuri & Rainfed & Alluvial Soil & $5-11 \%$ & 8.81 \\
\hline 6 & Kolarash & Shivpuri & Rainfed & Alluvial Soil & $3-9 \%$ & 6.14 \\
\hline 7 & Badarwas & Shivpuri & Rainfed & Alluvial Soil & $5-10 \%$ & 6.97 \\
\hline 8 & Binaganj & Guna & Rainfed & Alluvial Soil & $2-6 \%$ & 3.93 \\
\hline 9 & Guna & Guna & Irrigated & Alluvial Soil & $0-4 \%$ & 1.94 \\
\hline 10 & Raghogarh & Guna & Rainfed & Alluvial Soil & $3-11 \%$ & 7.26 \\
\hline 11 & Rudhiyai & Guna & Rainfed & Alluvial Soil & $5-9 \%$ & 6.57 \\
\hline 12 & Biaora & Rajgarh & Irrigated & Medium black soil & $3-8 \%$ & 6.14 \\
\hline 13 & Sarangpur & Rajgarh & Rainfed & Medium black soil & $4-14 \%$ & 11.24 \\
\hline 14 & Sajapur & Sajapur & Rainfed & Medium black soil & $7-13 \%$ & 10.63 \\
\hline 15 & Makshi & Sajapur & Rainfed & Medium black soil & $4-15 \%$ & 9.47 \\
\hline 16 & Panchor & Sehore & Rainfed & Medium black soil & $8-13 \%$ & 11.98 \\
\hline 17 & Dewas & Dewas & Irrigated & Medium black soil & $6-11 \%$ & 8.36 \\
\hline 18 & Mau & Indore & Rainfed & Deep black soil & $12-17 \%$ & 15.09 \\
\hline 19 & Barwaha & Khargone & irrigated & Deep black soil & $5-11 \%$ & 8.93 \\
\hline 20 & Bhikangaon & Khargone & Rainfed & Deep black soil & $12-22 \%$ & 17.68 \\
\hline 21 & Khargone & Khargone & Irrigated & Deep black soil & $8-11 \%$ & 9.57 \\
\hline 22 & Segaon & Khargone & Rainfed & Deep black soil & $11-18 \%$ & 15.07 \\
\hline 23 & Deshgaon & Khandwa & irrigated & Deep black soil & $5-12 \%$ & 8.67 \\
\hline 24 & Khandwa & Khandwa & Rainfed & Deep black soil & $12-19 \%$ & 15.91 \\
\hline 25 & Asirgarh & Burhanpir & Irrigated & Medium black soil & $6-11 \%$ & 8.73 \\
\hline 26 & Bhurhanpur & Burhanpir & Rainfed & Medium black soil & $15-21 \%$ & 18.28 \\
\hline 27 & Jhulwania & Barwani & Rainfed & Medium black soil & $12-17 \%$ & 14.53 \\
\hline 28 & Sendwa & Barwani & Rainfed & Medium black soil & $11-24 \%$ & 17.69 \\
\hline 29 & Rajpur & Barwani & Irrigated & Medium black soil & $7-11 \%$ & 9.06 \\
\hline 30 & Barwani & Barwani & Irrigated & Deep black soil & $4-9 \%$ & 6.54 \\
\hline 31 & Kukshi & Dhar & Irrigated & Deep black soil & $6-9 \%$ & 7.97 \\
\hline 32 & Bagh & Dhar & Rainfed & Deep black soil & $13-21 \%$ & 17.35 \\
\hline 33 & Sardarpur & Dhar & Rainfed & Medium black soil & $15-22 \%$ & 18.61 \\
\hline 34 & Dhar & Dhar & Rainfed & Medium black soil & $11-18 \%$ & 15.66 \\
\hline 35 & Ghatabillor & Dhar & Rainfed & Medium black soil & $4-14 \%$ & 10.91 \\
\hline 36 & Betma & Dhar & Irrigated & Medium black soil & $2-8 \%$ & 6.54 \\
\hline 37 & Bhabra & Jhabua & Irrigated & Deep black soil & $5-11 \%$ & 7.73 \\
\hline 38 & Jhabua & Jhabua & Rainfed & Medium black soil & $14-23 \%$ & 18.67 \\
\hline 39 & Mangode & Alirajpur & Irrigated & Medium black soil & $8-13 \%$ & 9.27 \\
\hline 40 & Alirajpur & Alirajpur & Rainfed & Deep black soil & $12-18 \%$ & 14.19 \\
\hline
\end{tabular}


Table 2: occurrence of major chickpea diseases in different soil types and irrigation condition

\begin{tabular}{|c|c|c|}
\hline \multirow{2}{*}{ Irrigation conditions } & \multicolumn{2}{|c|}{ Dry root rot incidence (\%) } \\
\cline { 2 - 3 } & Range & 11.37 \\
\hline Rainfed & $1.69-18.67$ & 7.65 \\
\hline Irrigated & $1.94-9.57$ \\
\hline \multicolumn{2}{|c|}{} \\
\hline \multirow{2}{*}{ Soil types } & Dry root rot incidence (\%) \\
\hline Alluvial & Range & Average \\
\hline Medium black & $1.69-8.81$ & 12.10 \\
\hline Deep black & $6.14-18.67$ & 12.06 \\
\hline
\end{tabular}

\section{3: Diseases and soil types}

During the survey, three types of soil were recorded in which chickpea crop cultivated. Maximum 17 places recorded under medium black soil followed by deep black soil (12 places) and alluvial (11 places). Medium Black (12.10\%) and deep black soil (12.06\%) found more suitable for development of wilt incidence compared to alluvial soil (5.06\%). Manjunatha et al. (2011) ${ }^{[11]}$ conducted survey during Rabi season in 2008 revealed that dry root rot of chickpea varied from locality to locality, obviously due to different soil conditions (Black/Red soil conditions). Khan et al. (2012) ${ }^{[10]}$ agreed with this finding.

\section{References}

1. Anonymous. Online Agricultural Statistics 2018a http/www.faostat.org.

2. Anonymous. Annual report, Directorate of Pulses Development, Government of India Ministry of agriculture and Farmers Welfare 2018, p8.

3. Bhatti MA, Kraft JM. Effects of inoculum density and temperature on root rot and wilt of chickpea. Pl. Dis 1992;76:50-54.

4. Butler EJ. Fungi and Diseases in Plants. Thacker Spink and Co., Calcutta, India 1918, 547.

5. Dhawan K, Malhotra S, Dahiya BS, Singh D. Seed protein fractions and amino acid composition in gram Cicer arietinum. Pl. Foods Human Nutr 1991;41:225232.

6. Dubey SC, Singh SR, Singh B. Morphological and pathogenic variability of Indian isolates of Fusarium oxysporum f. sp. ciceris causing chickpea wilt. Arch. Phytopathol. 2010;43:174-189.

7. Ghosh R, Sharma M, Telangre R, Pande S. Occurrence and distribution of chickpea diseases in central and southern parts of India. American J Pl. Sci 2013;4:940944.

8. Haware MP. Fusarium wilt and other important diseases of chickpea in the Mediterranean area. Options Méditerraneennes Séries 1990;9:163-166.

9. Jalali BL, Chand H. Chickpea wilt. In: Plant Diseases of International Importance. Diseases of Cereals and Pulses (U.S. Singh, A.N. Mukhopadhayay, J. Kumar, H.S. Chaube, ed.), Prentice Hall, Englewood Cliffs, NJ, USA 1992;1:429-444.

10. Khan RA, Bhat TA, Kumar K. Management of chickpea (Cicer arietinum L.) dry root rot caused by Rhizoctonia bataticola (Taub.) Butler. Int. J. Res. Pharma. Biomedi. Sci 2012;3(4):1540-1548.

11. Manjunatha SV, Naik MK, Patil MB, Sudha S. Prevalence of dry root rot of chickpea in north-eastern Karnataka. Karnataka J Agric. Sci 2011;24(3):404-405.

12. Mina U, Dubey SC. Effect of environmental variables on development of Fusarium wilt in chickpea (Cicer arietinum) cultivars. Indian J Agric. Sci 2010;80(3):231234.

13. Navas-Cortés JA, Alcalá-Jiménez AR, Hau B, JiménezDíaz RM. Influence of inoculum density of races 0 and 5 of Fusarium oxysporum f. sp. ciceris on development of Fusarium wilt in chickpea cultivars. European $\mathrm{J}$ Pl. Pathol 2000;106:135-146.

14. Nene YL, Reddy MV. Chickpea diseases and their control. In: The Chickpea, (M.C. Saxena, K.B. Singh, ed.), CABI Publishing, CAB International, Wallingford, UK 1987, 233-270. 